\title{
A STUDY OF THE HEMOLYTIC ACTIVITY OF THE SPLEEN IN PERNICIOUS ANEMIA*
}

\author{
OSWALD H. ROBERTSON, M.D. \\ BOSTON
}

There is a certain amount of evidence that the increased blood destruction occurring in pernicious anemia is in some way associated with an abnormal functioning of the spleen, since removal of this organ brings about a marked reduction in the quantity of blood destroyed. This reduction has been found in almost every instance where the blood destruction was studied before and after splenectomy. ${ }^{1}$ Eppinger and Ranzi ${ }^{2}$ and the author, ${ }^{3}$ who report the two largest series of cases, found that the greatly increased hemolysis present before operation showed a constant and marked decrease afterwards, reaching normal in all but two or three cases. Yet the manner in which the spleen acted to produce increased blood destruction is as yet undetermined.

The literature contains comparatively few observations on the hemolytic activity of the human spleen either in normal or pathological conditions. Benard ${ }^{4}$ tested salt solution extracts of two freshly excised normal human spleens and obtained negative results. In a case of severe hemolytic anemia with marked jaundice, Antonelli ${ }^{5}$ was unable to demonstrate any hemolytic activity with a saline extract of the freshly excised spleen. Port ${ }^{6}$ studied the spleen in one case of pernicious anemia immediately after operation, using both alcoholic and ethereal extracts. His results were entirely negative. McPhedran, ${ }^{7}$ however, working with ethereal extracts, found a substance in the spleen obtained at postmortem from a case of pernicious anemia, which possessed a strong hemolytic action. This hemolysin, which belonged to the group of unsaturated fatty acids, could, however, be extracted from the liver and intestinal wall and was also found in normal organs other than the spleen.

* Submitted for publication June 8, 1915

* From the Pathological Laboratory of the Massachusetts General Hospital

1. The quantitative estimation of urobilin in the stool was used as an index to the degree of blood destruction.

2. Eppinger, H., and Ranzi, E.: Mitt. a. d. Grenzgeb. d. Med. u. Chir., 1914. xxvii, 796 .

3. Robertson, O. H.: The Archives Int. Men., 1915, xri, 429.

4. Benard, H.: Thèse de Paris, 1913.

5. Antonelli: Progressive Med., June, 1914, p. 327.

6. Port, Fr.: Berl. klin. Wchnschr., 1914, li, 546.

7. McPhedran, W. F.: Jour. Exper. Med., 1913, xviii, 527. 
Several writers have suggested the possibility that the abnormal amount of hemolysis occurring in pernicious anemia may take place in the portal system, first on account of the lack of any evidence of hemolysis in the peripheral circulation, and second, because the chief deposit of iron is found in the liver. In a case of pernicious anemia with splenectomy, Eppinger ${ }^{8}$ tested the hemolytic properties of the blood obtained from the splenic vein at operation with a negative result. $\mathrm{Huber}^{9}$ in a similar case tested the resistance of the unwashed red blood cells from the splenic vein against hypotonic salt solutions. He found no difference between the splenic vein blood cells and the cells from the peripheral circulation.

In view of the few observations which have been made on this subject, it seemed desirable to record the results of a study of the freshly excised spleen and splenic vein blood in six cases of pernicious anemia recently in which the patients were operated on at the Massachusetts General Hospital for splenectomy.

\section{SPLEEN}

A histological study of the spleen in these cases was practically negative. There was no abnormal phagocytosis, no pigmentation, nor any other evidence of increased hemolysis.

The saline extract for the following experiments was made by adding to finely ground up fresh spleen pulp, twice its volume of normal salt solution. The mixture was then agitated in a mechanical shaker for one hour and finally centrifugated at high speed till no further sediment could be obtained. A very small quantity of red cells0.05 c.c. of a 2 per cent. suspension-was added to varying quantities of this extract, and after two hours at $37 \mathrm{C}$., the mixtures were centrifugated and read. There was no hemolysis either with the patients, or with normal cells.

Acting on the assumption that if conditions similar to those in the body were maintained, the result might be different, in the next case the spleen was kept warm and the process maintained at $37 \mathrm{C}$. throughout. Under such conditions there was likewise no hemolysis. Benard stated in his experiments with dogs that he obtained a splenic extract actively hemolytic for the animal's own cells only when he perfused the spleen thoroughly with salt solution beforehand. Perfusion of the spleen in a third case made no difference, nor did keeping the extract for several days, which according to Widal Abrami and Brule $^{10}$ tends to increase the hemolytic properties of the spleen extract.

8. Eppinger, H.: Berl. klin. Wchnschr., 1913, 1, 2409.

9. Huber, O. R. C.: Berl. klin. Wchnschr., 1913, I, 2179.

10. Widal Abrami and Brule: Bull. Soc. d. hôp. de Paris, 1912, No. 13. 
An alcoholic extract was next tried. This was prepared by shaking finely ground up spleen pulp with 95 per cent. alcohol for several hours. The supernatant fluid was then decanted, evaporated to dryness, and the residue taken up with salt solution. This extract also failed to hemolyze red blood cells.

On account of Port's negative finding with the ethereal extract of a freshly excised pernicious anemia spleen, a portion of one spleen was extracted with ether. This extract showed an intensely hemolytic action, though not quite as strong as that found by McPhedran in the pernicious anemia spleen at postmortem. McPhedran's findings make it apparent that the extraction of the fatty hemolysins offers very little hope of differentiating the pernicious anemia spleen from the normal spleen.

This absence of any evidence of hemolytic activity characteristic of the pernicious anemia spleen, coincides with the negative histological findings. It is still possible that the spleen does possess a hemolysin, but that the methods used in attempting to extract it are unsuitable to demonstrate its presence.

\section{SPLENIC VEIN BLOOD}

Blood from the splenic vein was obtained at operation by aspiration into a syringe before the pedicle of the spleen was ligated. Owing to the difficulties in technic, the blood in two cases began to clot in the syringe, or so soon after drawing that it was not available for all the tests.

Hemolytic Properties. - The plasma in the three cases in which the blood was obtained before clotting occurred, showed free hemoglobin; in two the plasma was definitely pink, in the third hemoglobin was evident spectroscopically. The presence of hemolysis here, however, can easily be accounted for as a result of manipulation during the delivery of the spleen from the abdominal cavity. Hemolytic experiments were made in two cases with the serum, using both the patient's own blood cells and normal cells, and as controls, serum taken from the patient's arm vein immediately before operation and serum from a normal person. Results were entirely negative and the addition of guineapig complement made no difference.

Morphology.-Blood counts varied in their relations to those of the peripheral blood. One case showed a considerably increased number of red blood cells in the splenic vein, the other showed somewhat fewer. The white counts were both higher in the splenic vein, while the differential counts were practically identical with those of the peripheral blood. These variations from the peripheral blood cannot be relied on as representing actual differences, on account of the factor 
of error due to the above mentioned manipulation, during which process a larger number of cellular elements than normal may have been squeezed into splenic vein.

The appearance of the red blood cells was identical with that shown by the peripheral blood, with the exception that in one case there was a greater percentage of reticulated cells in the blood from the splenic vein. Blood platelets were strikingly abundant in spite of the fact that they were much diminished in the peripheral circulation. The fact that the spleen normally is a great storehouse for blood platelets, however, coupled with the factor of manipulation at operation, may well explain their great increase in the splenic vein at this time.

Resistance of the Red Blood Cells.-The only positive finding which could not be explained as a result of operative procedure, was the decreased resistance of the red cells from the splenic vein. This was constant in the three cases tested. For controls the patient's blood taken immediately before operation and normal blood were used.

\begin{tabular}{|c|c|c|}
\hline & $\begin{array}{l}\text { Hemolysis } \\
\text { Beginning at }\end{array}$ & $\begin{array}{l}\text { Hemolysis } \\
\text { Complete at } \\
\text { Pct Salt Sol }\end{array}$ \\
\hline Case 1.- $\begin{aligned} \text { Splenic vein blood } & \ldots \ldots \ldots \ldots \ldots \\
& \text { Peripheral blood } \ldots \ldots \ldots \ldots \ldots \\
& \text { Control normal blood } \ldots \ldots \ldots\end{aligned}$ & $\begin{array}{ll}\text { Pct. Salt Sol. } \\
\quad 0.525 \\
& 0.45 \\
& 0.45\end{array}$ & $\begin{array}{l}\text { Pct. Salt Sol. } \\
0.325 \\
0.30 \\
0.325\end{array}$ \\
\hline Case 2.- $\begin{aligned} \text { Splenic vein blood } & \ldots \ldots \ldots \\
& \text { Peripheral blood } \ldots \ldots \ldots \\
& \text { Control } ~-\text { normal blood } \ldots \ldots\end{aligned}$ & $\begin{array}{l}0.675 \\
0.425 \\
0.425\end{array}$ & $\begin{array}{l}0.325 \\
0.30 \\
0.325\end{array}$ \\
\hline Case $3 .-$ Splenic vein blood $\ldots \ldots \ldots \ldots$ & $\begin{array}{l}0.675 \\
0.525\end{array}$ & $\begin{array}{l}0.35 \\
0.35\end{array}$ \\
\hline
\end{tabular}

In Case 2 the hemolysis, beginning at 0.675 per cent. was very faint and continued faint to 0.425 when it increased markedly. Case 3 showed well-marked hemolysis beginning at 0.675 . In this case the blood was obtained from the spleen five to ten minutes after excision, which may account for a greater decrease in resistance than was shown by the other two cases. Huber's negative result might be accounted for by the fact that he did not wash the blood cells before testing their resistance, since unwashed cells are protected to a certain extent by the blood plasma present.

Banti ${ }^{11}$ obtained blood from the splenic vein at operation in two cases, one a case of hemolytic splenomegaly and the other a splenic vein thrombosis. Both showed a decreased resistance of the cells from the splenic vein. Banti also compared the resistance of the splenic vein blood cells with that of the peripheral cells in dogs and found a slight but constant lowered resistance in the cells of the splenic vein. This difference in resistance was much increased after the

11. Banti: Semaine méd., 1913, p. 313. 
injection of a hemolytic serum, suggesting that a possible normal function of the spleen had become markedly hyperactive. It seem: not improbable that the decreased resistance found in the cells of the splenic vein in these cases of pernicious anemia, which was even greater than that in Banti's dogs, may have the same significance, i. e., an evidence of injury received by the cells during their passage through the spleen due to some toxic substance elaborated by that organ. These injured cells would then be more easily broken down in other parts of the body. In this way the absence of any direct hemolytic action of the spleen could be accounted for.

It was thought possible that this change in resistance might be duplicated in vitro by allowing the cells to remain in contact with splenic extract. The patient's peripheral blood cells as well as normal cells were incubated for two hours with the saline extract, then washed and their resistance to salt solution tested. No change in resistance was observed. Neither were they less resistant to a hemolytic serum after this procedure.

\section{SUMMARY AND CONCLUSIONS}

1. In a study of the hemolytic activity of the fresh spleen obtained at operation, from six patients with pernicious anemia, it was found that extracts of the spleen pulp made with both normal salt solution and alcohol, possessed no hemolytic properties. An ethereal extract, on the other hand, showed a marked hemolytic action. However, the hemolytic substance contained in this extract belonged to the group of unsaturated fatty acids and has been obtained in equally strong concentration from the normal liver and intestine.

2. The only change in the splenic vein blood obtained at operation, which could not be accounted for by manipulation, was a decreased resistance of the red cells. These cells were definitely less resistant than those of the peripheral circtulation in the same individual and in normal controls.

3. The above findings seem to exclude any gross or easily demonstrable manifestation of hemolytic activity on the part of the spleen. However, the decreased resistance of the red cells in the splenic vein, would suggest that the spleen in pernicious anemia elaborated some toxic substance or enzyme which so injures the blood cells during their passage through that organ that they are more susceptible than normally to destruction elsewhere. It seems probable that in some other part of the body there is elaborated an abnormal hemolysin or an abnormally acting normal hemolysin. 